\title{
Discurso e (trans)identidades: interação, intersubjetividade e acesso à prevenção de DST/AIDS entre travestis
}

\author{
Discourse and (trans)identities: interaction, \\ intersubjectivity and access to STD/AIDS \\ prevention among travestites
}

Rodrigo Borba*

Universidade Federal do Rio de Janeiro - UFRJ

\begin{abstract}
RESUMO: Neste artigo, investigam-se as dinâmicas discursivo-identitárias emergentes de eventos de fala co-construídos entre travestis que se prostituem e mulheres ativistas na prevenção de DST/AIDS. Através de uma perspectiva socioconstrucionista do discurso e das identidades sociais (MOITA LOPES, 2003), o estudo analisa os processos de (re)construção, (re)negociação e administração de diferenças (percebidas ou construídas) entre as interagentes. Mais especificamente, analisam-se as táticas de intersubjetividade (BUCHOLTZ; HALL, 2003, 2004, 2005), construídas entre as participantes no processo interacional que coloca suas performances identitárias habitualizadas em fricção. As análises apontam para o caráter fluido, multifacetado, fragmentado e sempre movente das identidades sociais que, em interaçóes nas quais identidades díspares se tencionam, recompóemse constantemente na administração das diferenças entre interlocutores/as.
\end{abstract}

PALAVRAS-CHAVE: identidade, intersubjetividade, linguagem e gênero, transgênero, prevenção de DST/AIDS

ABSTRACT: This paper investigates the discursive and identity dynamics that emerge from speech events co-constructed by travestites who work as sex professionals and two female safer-sex outreach workers. Guided by a socioconstructionist perspective on the relations between discourse and social identities (MOITA LOPES, 2003), the study analyses the processes of (re)construction, (re)negotiation, and management of (perceived or constructed) differences among the interlocutors. More specifically, following Bucholtz and Hall (2003, 2004, 2005), I analyse the tactics of intersubjectivity produced by the interlocutors in the interactional process that put their differing identities in friction. The analysis indicates that identities are always fluid, multilayered, fragmented and changeable. This flexibility of social identities is highly visible in

* borba.rodrigo@terra.com.br 
interactions that put differing identities in tension, bringing about the necessity of constant re-makings of subject positions to administrate the differences among interlocutors.

KEYWORDS: identity, intersubjectivity, language and gender, transgender, STD/AIDS prevention

\title{
Fricções de alteridades: contemporaneidade, identidades e discurso ${ }^{1}$
}

\author{
Provavelmente, quanto maior é a diferença, \\ maior será a igualdade, e quanto maior é a igualdade maior \\ a diferença será $[\ldots]$ \\ (Saramago, 1997, p. 97)
}

No mundo contemporâneo, vivemos em sociedades caracterizadas pela insistente e acelerada proliferação de identidades. Novas categorias sociais, novas comunidades, novos estilos de vida surgem e convivem com os que por aqui já circulavam. As identidades tradicionais e consideradas como bem estabelecidas - hegemônicas - são constantemente defrontadas com novas formas de viver a vida social (novas configuraçōes de gênero, classe social, sexualidade, profissão) e, assim, têm seu status e poderio desafiado (ou, no mínimo, questionado) pelo diferente. É só sair de casa que seremos interpelados pelo Outro; ou como afirma Bauman (2005, p.19), "as identidades flutuam no ar, algumas de nossa própria escolha, mas outras infladas e lançadas pelas pessoas a nossa volta”. Somos, desse modo, frequentemente "convidados ou mesmo intimados a repensar nossas vidas sociais" (MOITA LOPES, 2003, p.17). O contato com o Outro gera dinâmicas socioculturais, políticas, discursivas e interacionais que nos forçam a rever nossos posicionamentos, ou, pelo menos, a ver que há múltiplas formas de ser, de lidar com a sexualidade, com o corpo, com o gênero, com a religião. A proliferação de novas configurações identitárias nos impele diariamente a processos de 'fricção de alteridades' (BORBA, 2008a), ou seja, o encontro de indivíduos que se constroem em categorias identitárias tradicionais ou hegemônicas com outros que se posicionam em novas categorias identitárias de gênero, sexualidade, classe social, profissão.

${ }^{1}$ Esta discussão deriva da pesquisa realizada no Programa Interdisciplinar de Linguística Aplicada da Universidade Federal do Rio de Janeiro sob supervisão do Prof Dr. Luiz Paulo da Moita Lopes a quem agradeço pela parceria, pelos conselhos, pela amizade e pelas utopias compartilhadas. 
Este artigo investiga uma fatia desse complexo processo de fricçōes: interaçōes entre travestis profissionais do sexo e duas mulheres funcionárias (a advogada e a secretária) de uma ONG a qual denomino de ONG Liberdade ${ }^{2}$ que visa à melhoria da qualidade de vida de indivíduos transgênero na Cidade do Sul, uma região urbana no sul do Brasil. Para ilustrar o processo de fricçôes identitárias provocado pela presença das travestis em nossa sociedade, levemos as cenas a seguir, extraídas dos meus diários de campo, em consideração:

\section{Cena 1}

Era domingo e chovia; um dia viscoso com cheiro de terra: clima típico da Feira do Livro de Porto Alegre. No entanto, o charme século-dezenove da Praça da Alfândega estava mais cintilante com os ipês floridos. Na tentativa de comprar um livro, lá estava eu no meio da multidão de leitores e leitoras, visitando cada stand, sem sucesso. O tédio já me dominava. Com um mau-humor sulfúrico, causado pela decepção de não ter encontrado o desejado livro, aviso meus amigos que iria embora. Porém, algo inesperado me fez mudar de ideia. Entre as centenas de ávidos/as leitores/as, avisto uma que me chama atenção, uma leitora-travesti (fui a ela apresentado dias depois, e aqui me refiro a essa leitora como Clarissa). Caminhando entre o público, abrindo caminhos, com uma nonchalance adquirida com muito treinamento, essa leitora explorava os stands, sedenta por literatura. Surpreso, decido investigar que livro ela procurava. Sobre altissimos saltos, elegantemente vestida em uma calça jeans justissima e uma blusa negra de cetim, sua figura chamava a atenção de todos/as que, como ela, tentavam encontrar algum texto para seu deleite. Olhares curiosos, duvidosos. Comentários incrédulos. A travesti mantinha-se intacta. Quando me aproximei, ela, finalmente, encontrara seu livro. Tinha em suas mãos um livro de Clarice Lispector. Recebendo o troco do vendedor que perguntava: "Mais alguma coisa, senhor?" Clarissa, balançando seus loiros cabelos e, displicentemente, ajeitando o decote da blusa, assevera: senhorita! O vendedor, atrás do balcão, confuso, em voz baixa, ecoava as palavras de sua cliente, para, segundos depois,

\footnotetext{
${ }^{2}$ Por motivos de natureza ética, todos os nomes próprios utilizados no texto são pseudônimos.
} 
reclamar com seus colegas que "esse mundo está realmente perdido". [Diários de campo, 06/11/2005]

\section{Cena 2}

Copacabana, inverno carioca (35 graus!), ansioso a esperava para nosso primeiro encontro. Conhecia sua voz, já havíamos conversado por telefone para discutir os detalhes: hora (17:00) e local (Quiosque Rainbow, em frente ao luxuoso Copacabana Palace) sugeridos por ela. Quando a vi, algum tipo de senha absolutamente indecifrável me indicou: Valquiria. Caminhava resoluta em minha direção (talvez tivesse me identificado através do mesmo tipo de senha que, misteriosamente, me ajudou a reconhecê-la): sorriso largo e fácil, seios voluptuosos, andar languido, pleno de leveza, tudo isso displicentemente decorado por um vestido preto (bá-si-co!) com amplo decote. Cumprimentamo-nos e sentamos. Rodeados por clientes do bar, transeuntes e banhistas, Valquíria me contava sobre sua vida. Descobrira-se travesti muito cedo (13 anos), já não mais se prostituía depois de uma rentável temporada na Europa. De volta ao Rio de Janeiro, trocara o subúrbio por Copacabana. Mantinha dupla jornada de trabalho: como ativista de uma ONG e como funcionária pública em uma instância do governo municipal. Olhava frequentemente para o relógio: não podia se atrasar para o curso pré-vestibular; almejava cursar Comunicação em alguma universidade pública. Enquanto com ela conversava, Valquíria chamava a atenção dos que por ali passavam. A passos lentos, ofuscados pela figura opulenta da travesti, homens, mulheres, crianças nos observavam, passavam, olhavam para trás e comentavam. Risinhos de chacota, olhares escarninhos de "respeitáveis" senhoras, olhares curiosos dos homens (alguns claramente surpresos, outros, porém, deslumbrantemente desejosos) foram habitués de nosso encontro. Valquíria (cansada de guerra!) continuava fluente, cheia de si. Entre uma história e outra, não deixava de verificar o conteúdo das sungas expostas na praia. Mais olhares inquietantes, desestabilizados, curiosos. Valquiria, alheia ao frenesi que sua presença ali causava, afirmava, perspicaz: "Rodrigo, depois que se anda de saia e se coloca peito, pra que seguir protocolo?”. [Diários de campo, 29/07/2006] 
As travestis ${ }^{3}$ há tempos deixaram de ser obscuras; míticos seres pouco visíveis que habitavam somente os inóspitos territórios de prostituição dos grandes centros urbanos brasileiros. Elas já possuem "inscrição popular e social" (SILVA, 1996, p. 22), já estão incorporadas às nossas paisagens urbanas (SILVA, 1993, p. 53). Deixaram o "universo existencial restrito ao gueto" (PERES, 2004, p.121) e, assim, inauguram um processo de mudança político-social: impõem sua presença e mostram à sociedade a permeabilidade das fronteiras entre os gêneros e a possibilidade de viver nessas fronteiras ou de cruzá-las. As cenas descritas acima, observadas por um pesquisador do que Benedetti (2005) denomina de universo trans, poderiam ter sido presenciadas por qualquer morador/a de qualquer grande cidade brasileira. Somos constantemente defrontados/as com a travestilidade: ${ }^{4}$ em Copacabana, na tradicional Feira do Livro de Porto Alegre, no metrô em São Paulo, nos shopping centres, na televisão, nos ônibus, nas áreas de prostituição, no aterro do Flamengo, na Redenção, nos aeroportos, em nossa vizinhança. A circulação desses personagens em intensa relação com a sociedade abrangente (SILVA; FLORENTINO, 1996, p.107) nos apresenta, concretamente, a fragmentação e fluidez das identidades sociais (MOITA LOPES, 2002), a possibilidade do trânsito entre discursos de identidades nos quais podemos circular. Talvez os risos e olhares incrédulos dirigidos à Clarissa, no centro de Porto Alegre, e à Valquíria, em Copacabana, sejam pura e simplesmente frutos do preconceito que relega as travestis à margem de nossa sociedade. Talvez sejam provocados pela demonstração corporificada da possibilidade de uma mutação radical, acessível, em princípio, a qualquer pessoa, que desmantele a a estabilidade dos significados disponíveis: podemos nos tornar quem quisermos, uma vez que tenhamos acesso a discursos que nos possibilitem tal mudança. Essa é uma das desestabilizações causadas pelas travestis: um homem e uma mulher podem se transformar, corporal, discursiva e simbolicamente, em mulher e homem.

\footnotetext{
${ }^{3}$ Utilizo o feminino gramatical ao me referir às travestis durante o texto. Além de um posicionamento político, essa escolha converge com o uso feito por travestis nas mais diferentes localidades do Brasil na tentativa de construir sua identidade discursiva de acordo com sua performance de gênero (BUTLER, 2003). Para uma discussão sobre o assunto, ver Borba e Ostermann (2007, 2008).

${ }^{4}$ Peres (2004) cunha o termo travestilidade, em oposição a travestismo, pois, segundo o autor, esse termo contempla "a imensa complexidade das formas de expressão travesti existentes, considerando a heterogeneidade dos modos de ser no mundo que é configurado pela sub-cultura travesti” (p.120). Esse termo é adotado no decorrer deste artigo.
} 
Descrições sobre as dinâmicas interacionais em conversas espontâneas entre pessoas tradicionalmente generificadas e indivíduos transgêneros são inexistentes na literatura especializada disponível. Essa é uma das lacunas que este trabalho visa a preencher. Os estudos sobre indivíduos transgêneros (ver, por exemplo, BARRET, 1998, 1999; BENEDETTI, 2005; BENTO, 2006; BESNIER, 1997; BOLIN, 1988; EPPLE, 1998; HALL; O'DONOVAN, 1996; KULICK, 1998; WIKAN, 1978) têm analisado as flutuações identitárias em sua fala e sua construção como seres sociais através da manipulação de uma pletora de recursos discursivos como o sistema gramatical de gênero (HALL, 2002; HALL; O'DONOVAN, 1996; LIVIA, 1997; BORBA; OSTERMANN, 2007, 2008), as ideologias locais de gênero (BARRET, 1999; BESNIER, 1997; HALL, 2005), posições locais e globais através da alternância de códigos (BESNIER, 2003), entre outros. No entanto, é inexistente a documentação sobre como as pessoas que participam (cotidiana ou esporadicamente) do universo social compartilhado por transgêneros conversam com tais atores sociais. Kulick (1999, p. 615) indica que "precisamos saber mais sobre como os indivíduos transgêneros falam com outras pessoas em seus milieux, e precisamos saber como essas pessoas avaliam e respondem a essa fala". Tento encaminhar possíveis respostas a esse desafio lançado por Kulick (1999) ao investigar os processos de fricção de identidades produzidos durante as intervenções para prevenção de DST/AIDS, realizadas pela equipe da ONG Liberdade nas áreas de prostituição da Cidade do Sul.

Ademais, vislumbra-se, neste estudo, uma sugestão teórico-metodológica de alargamento do escopo analítico da Linguística Aplicada. Tenta-se, aqui, aproximar essa área do conhecimento a um contexto relativamente pouco investigado nos estudos linguísticos brasileiros: a prevenção de DST/AIDS. A educação para práticas sexuais seguras e a prevenção de DST/AIDS foi tema de um simpósio temático no encontro internacional da American Association of Applied Linguistics de 2007, na Califórnia (http://www.aaal.org/aaal2007/ index.htm), o que evidencia um interesse crescente da comunidade científica por tal contexto de pesquisa. Descrevo aqui as implicaçôes interacionais de somente um pequeno extrato do amplo processo de fricção de alteridades encontrado no mundo contemporâneo. Essa fatia, embora muito particular, pode ser considerada um bom exemplo dos atritos identitários encontrados em maior escala em nossa sociedade. Investigar a construção de identidades em tal evento discursivo pode ser um importante passo para poder compreender outros possíveis jogos de identidades (HALL, S., 2001) que nos circundam 
cotidianamente; jogos que marcam nossa vida social com instabilidade, fragmentação e fluidez. Com as mudanças tecnológicas, econômicas, científicas e culturais que acompanham os processos de globalização (BAUMAN, 2005), há uma proliferação de formas de vivenciar práticas identitárias que nos levam a "experimentar a heterogeneidade da vida humana de frente" (MOITA LOPES, 2003, p. 17), o que, por conseguinte, nos intima a repensar nossas identidades sociais, a colocá-las em xeque. Esse é o desafio apresentado pelos processos de fricção alteritárias salientes nas sociedades contemporâneas: o re-pensar constante sobre quem somos - e sobre quem podemos ser (ver FOUCAULT, 1995; MOITA LOPES, 2003; FABRÍCIO; MOITA LOPES, 2004).

Filio-me a uma perspectiva socioconstrucionista do discurso e das identidades sociais (MOITA LOPES, 2002; 2003) segundo a qual nossas identidades são construídas por meio do discurso, não havendo, assim, uma identidade única alocada na psiché dos indivíduos. Pelo contrário, as identidades são fabricadas no momento do engajamento em algum embate discursivo (MOITA LOPES, 2003; DAVIES; HARRÉ, 1990), sendo, assim, o resultado / efeito dos processos socioculturais e interacionais nos quais nos envolvemos cotidianamente (MOITA LOPES, 2001; 2005; HALL, K., 2005; BUCHOTLZ; HALL, 2004; BUCHOLTZ, 1999). Moita Lopes (2002) afirma que "as identidades sociais não estão nos indivíduos, mas emergem na interação entre os indivíduos agindo em práticas discursivas particulares nas quais estão posicionados" (p. 37). Desse modo, as identidades não estão prontas nem fixas, mas situadas em processos discursivos nos quais são construídas a partir de propósitos localmente negociados.

Ao considerar as identidades como construídas no / pelo / por meio do discurso, nos deparamos com seu caráter contraditório, fragmentado e processual, pois em cada prática discursiva os indivíduos podem se constituir diferentemente vis-à-vis o contexto sócio-histórico-cultural específico e vis-àvis os/as outros/as participantes da interação. Aqui, seguindo Moita Lopes $(2002,2003)$, aludo a dois aspectos importantes da visão socioconstrucionista adotada nesta investigação: a alteridade (BAKHTIN, 1979/2003; 1929/ 1997) e a situacionalidade (LINDSTROM, 1992). Em outras palavras, todo e qualquer discurso é produzido por alguém que tem marcas sócio-históricas particulares e é direcionado a alguém, com suas marcas identitárias, em um contexto de produção específico.

Os processos de construção discursiva de identidades sociais são intersubjetivos, dialógicos e relacionais (FABRÍCIO; MOITA LOPES, 2004) 
no sentido de que os efeitos de identidades produzidos pelo discurso são sempre postos sob o escrutínio do outro e são influenciados pelo contexto no qual os/as participantes discursivos estão inseridos/as. As características do discurso acima descritas (i.e., alteridade, situacionalidade e intersubjetividade) são pressupostos cruciais para compreendermos as interaçôes entre travestis e ativistas de prevenção de DST/AIDS aqui investigadas. Grosso modo, no que tange o aspecto situacional, tais interações são inseridas nos territórios de prostituição das travestis na Cidade do Sul - importantes locais para sua socialização e aprendizado de gênero (KULICK, 1998; BENEDETTI, 2005). No que se refere à alteridade, essas interações são estruturadas a partir do que aqui chamo fricção de alteridades, no sentido de que as interventoras (indivíduos que se constroem e são construídos como representantes de identidades hegemônicas - mulheres, brancas, heterossexuais, de classe média, profissionais liberais com diplomas universitários, mães) engajam-se no discurso com travestis cuja construção de identidades extrapola discursos tradicionais de gênero e sexualidade. Portanto, a alteridade de ambas as partes é uma categoria fundamental para investigarmos tais eventos discursivos.

\section{A zona de batalha: ${ }^{5}$ contexto e metodologia de pesquisa}

Os dados aqui analisados foram gerados em um período de 12 meses de trabalho de campo de cunho etnográfico durante o qual acompanhei o diaa-dia da ONG Liberdade e gravei em áudio eventos discursivos que constituem a rotina da $\mathrm{ONG}$, o que gerou um corpus de mais de 60 horas de gravações. A ONG Liberdade foi idealizada e fundada por um grupo de travestis politicamente engajadas na luta LGBTTT. ${ }^{6}$ A ONG planeja, organiza e implementa projetos com os mais diferentes propósitos. Neste artigo, ponho sob escrutínio o projeto que se constitui de intervençôes para entrega de preservativos às travestis enquanto essas se prostituem nas ruas da Cidade do Sul. Essas intervençōes acontecem às terças-feiras à noite, caso não chova e/ou o carro da ONG não esteja estragado. Normalmente, as interventoras Sandra e Márcia, indivíduos que têm se construído como mulheres em gênero e sexo, deixam a sede da Liberdade aproximadamente às 19 horas e percorrem cerca de quatro pontos de prostituição rueira nos quais as travestis vendem seus

\footnotetext{
5 Termo êmico utilizados por travestis para se referirem à prostituição.

${ }^{6}$ Lésbicas, Gays, Bissexuais, Travestis, Transexuais e Transgêneros.
} 
serviços, de norte a sul da cidade. Segundo o estatuto da ONG Liberdade, essas intervenções visam (1) à distribuição de preservativos e sachês de gel lubrificante às travestis e (2) ao anúncio dos diversos serviços prestados pela instituição, como as reuniōes que acontecem às quartas-feiras à tarde, workshops, aconselhamento sobre questôes legais, elaboradas por Sandra e outra advogada associada à $\mathrm{ONG}$, entre outros.

O corpus, para esta investigação, constitui-se de interações entre as interventoras e as travestis que recebem os preservativos. Tais interaçôes foram gravadas em áudio e transcritas segundo as convenções de transcrição sugeridas por Du Bois; Schuetze-Coburn; Paolino; Cumming (1992), que se encontram em anexo. Durante os meses de trabalho de campo, acompanhei a equipe em cinco intervenções. As interventoras abordavam aproximadamente 12 travestis por intervenção o que constitui um total de sessenta interações e mais de oito horas de gravação. Além das gravações, o corpus inclui fotos de cunho etnográfico feitas para enriquecer as análises de tais eventos de fala. É importante observar que antes da geração dos dados aqui descritos, todas as colaboradas da pesquisa assinaram um termo de consentimento informado, no qual permitiram a gravação de suas falas, sua transcrição, a elaboração das fotos e a utilização desses dados para fins de pesquisa. Esses documentos foram entregues e explicados às travestis por Sandra e Márcia durante as reuniōes da ONG Liberdade.

\section{As táticas de intersubjetividade: (re)construindo identidades na interação}

Para construir inteligibilidades sobre os embates discursivo-identitários estruturados durante as intervenções, o modelo analítico das táticas de intersubjetividade, proposto por Mary Bucholtz e Kira Hall (2005), serve de aparato teórico-analítico. Bucholtz e Hall (2005, p. 585-586) abordam a identidade "como um fenômeno relacional e sociocultural que emerge e circula em contextos discursivos locais". Para as autoras, as identidades são produtos/ efeitos de práticas socioculturais que somente podem ser investigadas por estudos etnográficos que analisem, com atenção, as performances locais dos indivíduos (BUCHOLTZ; HALL, 2003; 2004; 2005). Essas performances incluem tanto categorias de nível macro como posições culturais que emergem etnograficamente. É na intersecção entre o micro e o macro que as identidades são construídas por meio de performances locais que expressam em sua encenação as ideologias que informam essa construção. 
$\mathrm{O}$ termo táticas de intersubjetividade refere-se às maneiras pelas quais os/as falantes (des)alinham-se vis-à-vis seus/suas interlocutores/as (e vis-à-vis o contexto cultural em que estão inseridos/as) através do estabelecimento de uma plêiade de relações identitárias. Essas relações intersubjetivas sublinham o caráter situacional do discurso e sua inter-relação com a alteridade (a identidade do/a outro/a) na interação face-a-face, trazendo à baila negociaçōes e re-negociações das posiçóes de sujeito construídas por interagentes à medida que um embate discursivo se desenrola.

Bucholtz e Hall (2003, 2004, 2005) destacam os seguintes pares de táticas: adequação / distinção, autenticação / desnaturalização e autorização / deslegitimização. O primeiro par, adequação e distinção, constrói, respectivamente, relaçôes de semelhança e diferença entre participantes de um embate discursivo. Adequação refere-se às maneiras pelas quais um indivíduo (ou grupo de indivíduos) enfatiza semelhanças e, dessa forma, alinha-se a um grupo social do qual ele/a efetivamente não participa. Essa tática é utilizada na fabricação de semelhança suficiente (BUCHOLTZ; HALL, 2004, p. 495) entre interlocutores / as a partir do apagamento de características identitárias díspares. Em outras palavras, na interação, diferenças irrelevantes ou prejudiciais aos projetos identitários correntes podem ser minimizadas, e semelhanças percebidas como importantes para a construção de uma relação igualitária entre interagentes podem ser sublinhadas (BUCHOLTZ; HALL, 2005, p. 599). Discursivamente inventa-se a semelhança ao minimizar as diferenças. Em contrapartida, distinção é o processo de produção de diferenças sociais entre interagentes. Em vez de apagar diferenças para construir semelhança, essa tática é executada a partir da ênfase dada a diferenças percebidas ou construídas entre falantes. Segundo Bucholtz e Hall (2003, p. 384), “distinção é o mecanismo através do qual diferenças são produzidas” (ênfase no original). Dessa forma, os processos de distinção funcionam com base na supressão de semelhanças, construindo discursivamente os/as interagentes como participantes remotos dos grupos aos quais eles/as, por ventura, clamem por participação.

O segundo par de táticas, autenticação e desnaturalização, produz relações de autenticidade e falsidade / paródia com base em uma performance identitária que pode ser considerada como satisfatória ou não em comparação às posições de sujeito disponíveis localmente. Autenticação refere-se às ferramentas discursivas utilizadas por falantes para construírem-se como membros autênticos de categorias particulares. Essa tática baseia-se na construção de uma performance de identidade verídica, ou de uma performance identitária satisfatória 
para os padrões culturais disponíveis aos/às falantes. Com o processo de autenticação, chama-se a atenção para a produção de sentidos identitários que são somente alcançados com relação a outras identidades disponíveis nos contextos culturais locais. Bucholtz e Hall (2004, p. 498) indicam que "o termo autenticação enfatiza os processos através dos quais a autenticidade é construída, imposta ou percebida”. Através dessa tática, os/as interagentes "enfatiza $[\mathrm{m}]$ as maneiras pelas quais as identidades são discursivamente verificadas" (BUCHOLTZ; HALL, 2005, p. 601), i.e., como as identidades são validadas, consideradas como performances satisfatórias com base em discursos já sedimentados sobre determinadas categorias sociais. Desnaturalização, pelo contrário, refere-se ao processo pelo qual uma identidade é desestabilizada a partir de rupturas percebidas ou construídas em sua performance, produzindoa (1) como insatisfatória para os padrões locais ou (2) como descontínua e fragmentada. Dessa forma, a tática de desnaturalização chama a atenção dos/as interagentes para aspectos considerados problemáticos e/ou falsos da performance encenada (BUCHOLTZ; HALL, 2005, p. 602).

Finalmente, o par autorização / deslegitimação considera os aspectos institucionais e ideológicos dos processos de produção de identidade e suas relaçōes com estruturas de poder. Tais táticas constroem relações intersubjetivas de autoridade e ilegitimidade na tentativa de legitimar uma performance através de poder institucional ou de negar sua legitimidade através de resistência à autenticidade de sua encenação. Destarte, "autorização refere-se ao uso do poder para legitimar certas identidades sociais como culturalmente inteligíveis ao passo que deslegitimação refere-se à negação de tal validação" (BUCHOLTZ; HALL, 2004, p. 503). Essas táticas funcionam em relação muito próxima às táticas de autenticação e desnaturalização, pois questôes de legitimidade são freqüentemente ligadas a questôes de autenticidade. Ou seja, uma performance de identidade que pretende passar por autêntica deve, inevitavelmente, adotar práticas que legitimem sua encenação.

Faz-se necessário afirmar que as táticas são acima apresentadas separadamente como uma estratégia retórica para exemplificar as relações intersubjetivas por elas construídas. No entanto, em situações reais de fala, elas podem ocorrer isoladamente ou em conjunto no desenvolvimento de projetos identitários emergentes de uma determinada interação. Funcionando em conjunto, combinando-se, interpenetrando-se e modificando-se no decorrer de um evento de fala, as relações produzidas pelas táticas de intersubjetividade indicam que as identidades estão constantemente em devir; sempre dinâmicas 
e flexíveis - maleáveis às necessidades interacionais construídas em interações nas quais diferentes identidades são postas em fricção.

\section{De quando o tradicional defronta-se com o novo: a construção intersubjetiva de identidades entre interventoras e travestis}

Dedico-me, nesta seção, às análises das intervenções gravadas durante o trabalho com a ONG Liberdade. Afinal, que relações identitárias emergem dessas interaçõos? Como as diferenças (percebidas ou construídas) entre travestis e interventoras são (re)negociadas durante a entrega de preservativos na zona de batalha? Veremos, a seguir, que através de uma miríade de dispositivos linguísticos as interlocutoras assumem posicionamentos que produzem o efeito de identidades fragmentadas, fluidas e contraditórias ao administrar suas diferenças na interação.

\section{Semelhança suficiente: adequação às travestis}

O processo de adequação produzido por táticas de intersubjetividade envolve o apagamento de características potencialmente discordantes entre interagentes em favor de semelhanças percebidas ou construídas que são tomadas como mais relevantes para os propósitos identitários localmente construídos (BUCHOLTZ; HALL, 2003). No caso em tela, essas semelhanças são discursivamente construídas através de índices linguísticos (OCHS, 1992; SILVERSTEIN, 1985) que mobilizam posicionamentos discursivos (DAVIES; HARRÉ, 1990) e alocam as interlocutoras em categorias pertencentes ao universo da prostituição travesti. Esses índices são mecanismos sociolinguísticos que produzem ligações entre formas linguísticas e grupos sociais específicos. Tais ligações são produzidas por meio da repetição de determinadas formas linguísticas que passam a ser percebidas como "naturalmente" relacionadas a esses grupos.

No excerto 1, vemos Sandra construir duas identidades diferentes: a de travesti e a de cliente de travesti.

Excerto 1

18 Daniela: ai guria peguei um gripão que Deus o livre. e esse

19

20 Sandra: vento maldito ainda pra [ajudá::

21 Daniela: [vai dá chuva=

22 Sandra:

=não vai nada

oi princesa 


\begin{tabular}{ll}
23 Karla: & vai tê reunião [amanhã? \\
24 Márcia: & \multicolumn{1}{c}{ [tudo bom?* } \\
25 Sandra: & tem reunião amanhã. \\
26 Márcia: & amanhã tem. \\
27 & $(0,7)$ \\
28 Sandra: & vamo se aqüendá tudo lá. \\
29 & $(0,8)$ \\
30 Daniela: & vamo aqüendá o baco lá também?= \\
31 Sandra: & =também. \\
32 Daniela: & @@@@@ \\
33 Márcia: & ó uma sacolinha pra colocá o lixo. \\
34 Karla: & ai arrasô!= \\
35 Sandra: & =isso ai se chama:: profissional educada. jogue o \\
36 & lixo no [lixo.
\end{tabular}

Após o enquadre (GOFFMAN, 1974) ${ }^{7}$ de intervenção ter sido estabelecido, na linha 18, Daniela introduz outro enquadre, o de conversa cotidiana, o que possibilita a negociação discursiva de identidades que extrapolam a institucionalidade das interventoras nesse contexto. Esse novo enquadre é contextualizado (GUMPERZ, 2002 [1982]) pelo termo de referência "guria", que, na região sul do país, é associado à intimidade e à igualdade do status interacional. Tal termo configura uma troca situacional de códigos (BLOM; GUMPERZ, 2002 [1972]) no sentido de que, ao ser proferido, instaura (1) um novo enquadre e (2) uma nova relação social entre interventoras e travesti. Na linha 22, Sandra, ao notar a aproximação de Karla, a cumprimenta utilizando um enunciado que, segundo minhas informantes, é típico de seus clientes, "oi princesa", configurando, assim, um índice dessa identidade e posicionando a interventora nesse discurso de identidade. Dessa forma, Sandra desencadeia uma performance de cliente de travesti ao utilizar um posicionamento que as travestis reconhecem como característico dessa categoria.

$\mathrm{Na}$ linha 28, Sandra efetua outra alternância de códigos (BLOM; GUMPERZ, 2002 [1972]) utilizando a linguagem cifrada das travestis, o

\footnotetext{
${ }^{7} \mathrm{O}$ que chamo de enquadre de intervenção (BORBA, 2008a) é caracterizado pela orientação das interlocutoras à função institucional das interventoras no território de prostituição, ou seja, entregar preservativos, anunciar os serviços da ONG Liberdade e falar sobre sexo seguro. Tal enquadre é constantemente renegociado à medida que as interlocutoras orientam-se a outras questôes envolvidas na travestilidade.
} 
bajuba ${ }^{8}$ construindo o que Bucholtz e Hall (2004, p. 495) denominam semelhança suficiente. Em outras palavras, ao fazer uso do bajubá, Sandra parece diminuir suas diferenças identitárias ao construir-se como semelhante às travestis com quem interage. Esse processo de apagamento de características ideologicamente discordantes pode ser considerado como uma tática utilizada pela interventora na tentativa de produzir discursivamente uma performance identitária que não destoe do contexto onde está inserida durante as intervençôes. Dessa forma, Sandra posiciona-se, ao falar "vamo se aqüendá tudo lá", como travesti.

É interessante observar que aqüendar-se é um verbo com significados polivalentes. Esse termo pode ter vários sentidos, por exemplo, encontrar-se, prestar atenção, olhar e fazer sexo. O enunciado de Sandra (L. 28) pode ser traduzido por vamos nos encontrar todas lá. Porém, Daniela, aproveitando-se do fato de Sandra temporariamente suspender sua identidade institucional (construindo adequação a sua identidade), pergunta se durante a reunião "vamo aqüendá o baco lá também?” (L. 30) o que significa “vamos fazer sexo lá também?”. Sandra, jocosamente, afirma que sim. Tal informalidade nesse momento da interação pode ser creditada à performance de Sandra como travesti (L. 28), o que possibilita a re-significação das reuniōes da Liberdade como lugar erotizado.

O uso do bajubá é talvez a ferramenta linguística mais frequentemente utilizada pelas interventoras na negociação de suas posições-de-sujeito na batalha. Ao fazerem uso desse código, as interventoras convergem no uso de linguagem (BORTONI-RICARDO, 1984) com as travestis, construindo-se, assim, no mesmo universo social que suas interlocutoras transgênero. Vejamos mais um exemplo, no qual Sandra faz uso fluente do bajubá em sua construção identitária, posicionando-se, como veremos, no mesmo universo linguístico das travestis com quem interage.

\footnotetext{
${ }^{8} \mathrm{O}$ bajubá (ou bate) é composto por termos de algumas línguas africanas, principalmente o ioruba-nagô, sobre a base fonológica e gramatical do português. Ademais, há grande frequência de termos metonímicos e palavras estrangeiras foneticamente adaptadas ao português (ver SILVA, 1993; KULICK, 1998; BENEDETTI, 2005; PELÚCIO, 2005, 2007; BORBA, 2008b; BORBA; OSTERMANN, 2008).
} 


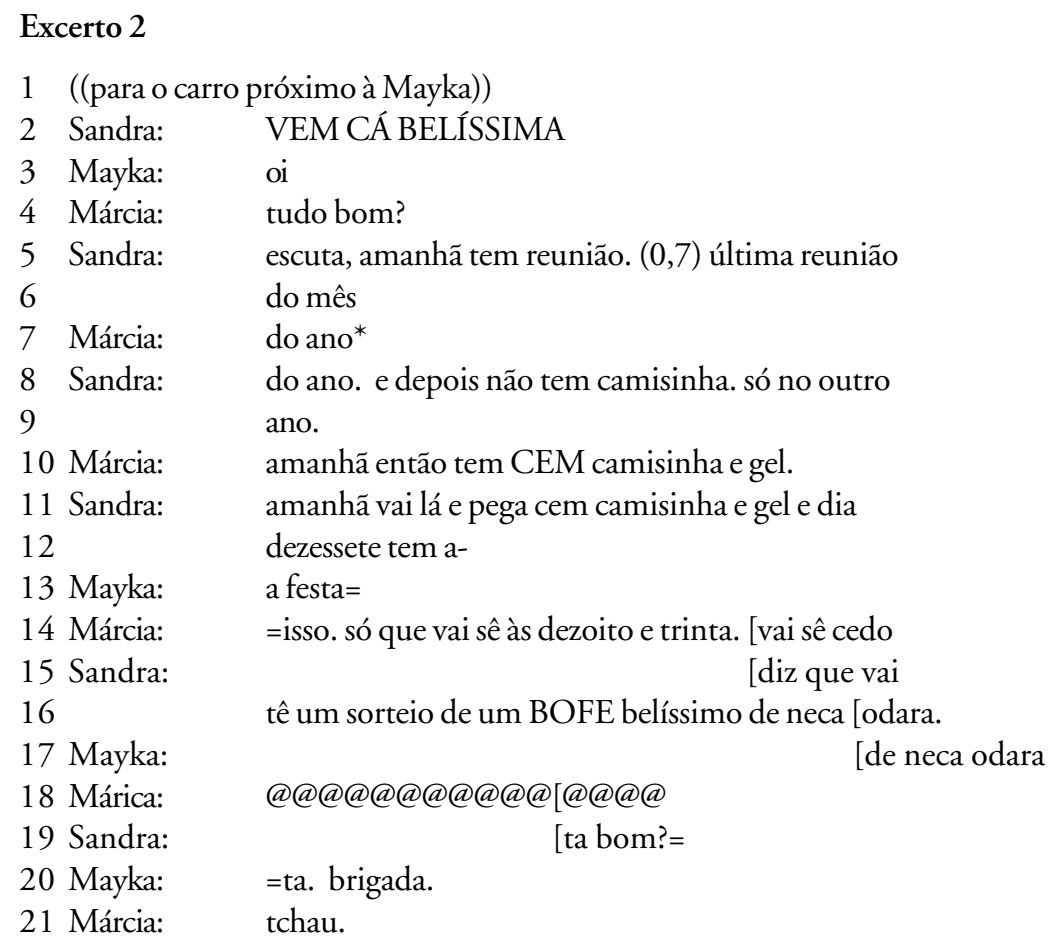

Essa intervenção foi gravada em novembro de 2003 quando a equipe da ONG Liberdade se preparava para encerrar os projetos financiados pelos governos Federal e Estadual, limitando-se, a partir de então, a questôes burocráticas e administrativas a serem resolvidas na sede da instituição. Aproveitando sua incursão nos territórios de prostituição, Sandra e Márcia, durante essa noite, avisavam as travestis sobre a última reunião do ano e sobre a festa de lançamento de um livro que a ONG estava organizando. No dia posterior a essa intervenção, haveria a distribuição de um grande número de preservativos e as interventoras tentavam convencer suas interlocutoras a participar desse encontro para abastecer seu estoque de camisinhas e gel lubrificante. Dessa forma, a identidade institucional de Sandra e Márcia é uma constante construção no excerto acima (L. 4-14) e emerge de sua orientação ao anúncio de questóes relativas ao funcionamento da ONG. No entanto, nas linhas 15 e 16, Sandra, provavelmente com o intuito de convencer Mayka a participar da "última reunião do ano", alterna códigos, posiciona-se em discursos do bajubá e, assim, engendra a encenação de uma identidade travesti, deixando temporariamente de lado sua identidade institucional anteriormente 
construída. Afirmando que, segundo boatos, haveria o sorteio de "um bofe belíssimo de neca odara", Sandra parece tentar motivar sua interlocutora travesti a participar da reunião. Esse enunciado indica que um homem com grande órgão sexual estaria à disposição das travestis presentes na reunião. Mayka parece orientar-se para esse fato e co-constrói o turno de Sandra através de uma sobreposição de falas (L.17). No dia seguinte, eu participei da "última reunião do ano" e pude perceber que, além de mim, mais nenhum "bofe" (belíssimo ou não) se encontrava na sala, o que corrobora minha suspeita de que Sandra pode ter utilizado essa informação como uma estratégia de convencimento para que Mayka participasse do encontro. Na quarta-feira à tarde, Mayka entra na sala, vestindo preto e óculos escuros ("chi-quér-ri-ma!"), quiçá, a aguardar o sorteio.

Como vimos, ao fazer uso de enunciados convencionalmente ligados às travestis e seus clientes, as interventoras re-ajustam, transformam, manipulam e recompõem suas construçōes tradicionais de identidades como interventoras e mulheres de classe média ao contexto onde a interação está inserida e às suas interlocutoras. Outro exemplo dessas re-contextualizaçôes identitárias, que é ilustrado no excerto 3 a seguir.

\section{Excerto 3}

53 Sandra:

54 Daniela:

55 Sandra:

56 Daniela:

57

58 Sandra:

59 Daniela:

60 Sandra:

61 Daniela:

62

63 Sandra:

64 Daniela:

65 Sandra:

66

67 Daniela:

68 Sandra:

69

70 Daniela:

71 Sandra: como é que ta a coisa aí? quem tem cliente tem quem não tem. é né. (tem que) tê um corpitcho!=

=tem que tê um um padrão né. tem que tê de tudo um pouco!

de tudo um pouco!=

=CLARO. e eles enlouQUECE já guria.

é verdade. qualqué dia desse eu vô te fazê um:[:

me ligô semana passada=

[a Sheyla

$=\mathrm{a}$ Sheyla::? =

=ahã. ela e a Cláudia.

ah/ manda um beijo pra ela. escuta:: a Júlia

vem vindo::?=

=vem. fa:[:la o que tu ia falá!=

[a passo bem (lento) =não. qualqué dia

desses vô ficá na tua esquina. tem lugar pra mim?= pode ficá. com certeza. Claro. tu sabe que sempre tem pra ti= =ta::: e me diz uma coisa, que cor o meu espartilho? 


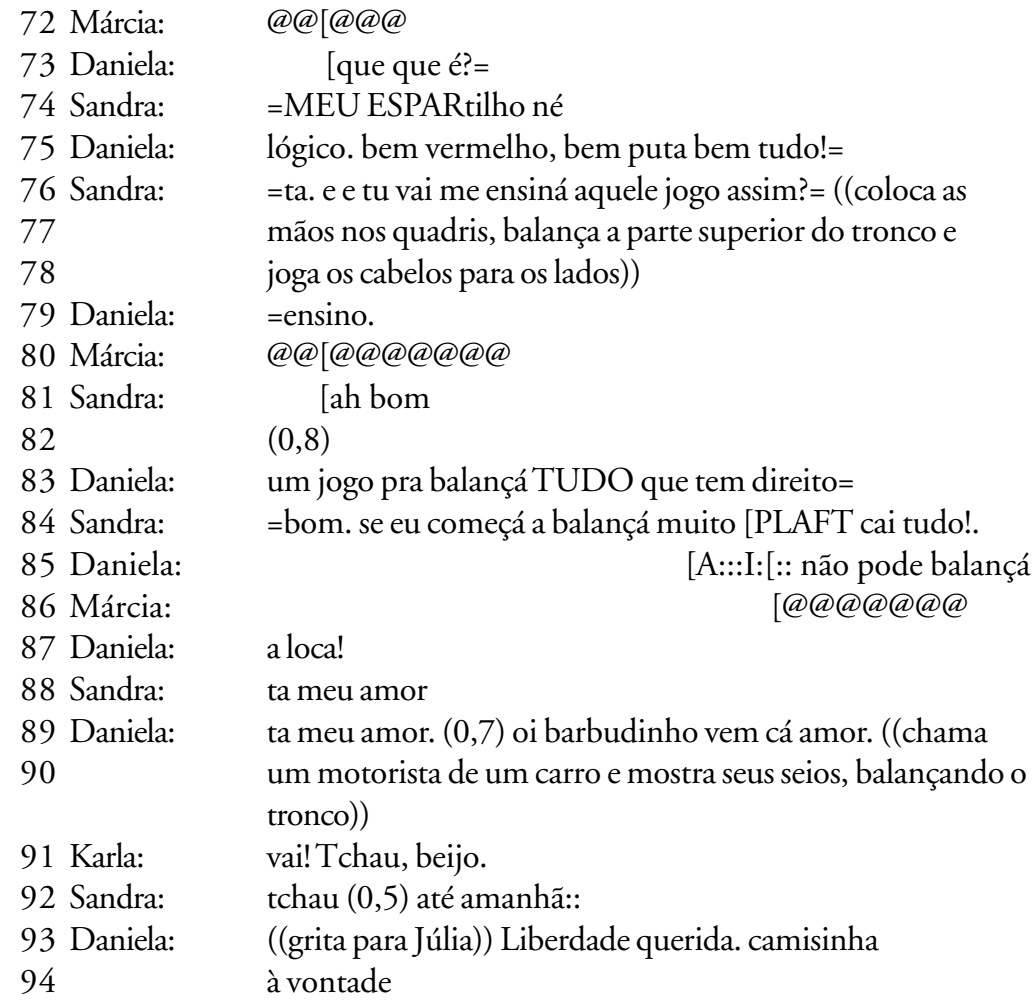

Da linha 53 à linha 60 acima, Sandra e Daniela comentam sobre a quantidade de clientes que circulavam na área naquela noite. À pergunta de Sandra, na linha 54, Daniela afirma que o número de clientes é considerável para aquelas travestis que já têm uma cartela de clientes bem consolidada. $\mathrm{Na}$ linha 55, a interventora sugere que, para se ter clientes, "tem que ter corpitcho", ou seja, deve-se ser jovem e estar em boa forma para que clientes em potencial se interessem pelas profissionais do sexo. Nesse momento, Daniela, sublinhando a ambiguidade do corpo travesti, enfatiza que "tem que ter de tudo um pouco". Podemos inferir com base nesse enunciado que, segundo a falante, para se ter clientes, no universo trans, deve-se construir um corpo no qual a feminilidade enfatizada (CONNEL; MESSERSCHIMIDT, 2005) das travestis é combinada com o órgão masculino (no bajubá, neca), que, segundo minhas colaboradoras, é uma importante ferramenta para se angariar clientes na batalha. Assim, de acordo com Daniela, quando se tem "de tudo um pouco" em um só corpo, os clientes "enlouquecem" (L.59). Após mais alguns turnos 
sobre uma travesti que Sandra e Daniela conhecem (L.61-65), Daniela pede para que a interventora retome o tópico iniciado na linha 60, mas abortado pelo assunto da ligação de Sheila, travesti que à época dessa gravação estava na França, onde foi trabalhar como profissional do sexo.

Diante da informação de que o número de clientes no território onde Daniela batalha pode ser bom, Sandra afirma que vai dividir com sua interlocutora seu ponto (L. 68-69), o que configura uma mudança de enquadre no qual a interventora indica seu interesse em prostituir-se com Daniela. A travesti, reconhecendo tal mudança, alinha-se positivamente ao novo posicionamento de Sandra e indica que a interventora tem passagem livre nesse contexto e que, se quiser, pode prostituir-se ali. Nesse momento, Sandra embute (GOFFMAN, 1974), na linha 71, um outro enquadre, um pedido de sugestão, e pergunta à sua interlocutora sobre um item de vestimenta muito utilizado entre as profissionais do sexo da Cidade do Sul. É nesse enquadre que a interventora, sublinhando o poder da travesti nesse contexto, pede a Daniela conselhos sobre sua possível vestimenta: "que cor o meu espartilho?" (L. 71). Daniela parece não ter entendido o que Sandra afirmara (afinal, como uma advogada poderia pedir tal informação?) e, na linha 73 , pede à interventora que repita a pergunta. Sandra imediatamente reitera, em volume elevado, a informação de que precisa (L. 74). É aí que Daniela ratifica a identidade recém produzida por Sandra, orientando-se a essa performance e dizendo que, para ser prostituta (e ter muitos clientes), ela deve usar um espartilho "bem vermelho, bem puta, bem tudo".

Tendo em perspectiva a experiência de Daniela como profissional do sexo, na linha 76, há um outro re-enquadramento na interação que, com o enquadre de pedido de sugestão negociado nas linhas 71-75, configura uma inversão da assimetria das intervenções. Sandra, nesse momento, sublinha o poder simbólico de sua interlocutora e pede que ela a ensine um movimento corporal bastante utilizado pelas travestis da cidade do sul para atrair seus clientes. Entre as linhas 76 e 85, Sandra e Daniela co-constroem e consolidam a negociação de uma identidade de prostituta para a interventora, negociação inicialmente sugerida pelo alinhamento de Sandra ao contexto de prostituição de Daniela e aos ganhos financeiros da travesti.

Vemos, com base nas análises acima, que as performances de identidades habitualizadas das interventoras são, durante as intervenções, deixadas em suspenso, o que desencadeia um processo local e sequencial de adequação às travestis e ao território de prostituição. Mas adequação não é a única tática que emerge dessas intervenções. 


\section{Autenticação da travestilidade}

A segunda tática de intersubjetividade empregada pelas interventoras constitui um processo de autenticação ou, como Bucholtz e Hall (2003) indicam, validação da identidade travesti. Um exemplo desse processo de validação da travestilidade pode ser encontrado no excerto 3. Sandra e Daniela conjuntamente constroem uma identidade de prostituta para a interventora por meio de índices que a alocam em tal categoria (i.e., permissão para se prostituir em um ponto específico, conselhos sobre a possível vestimenta de Sandra, itens que compõem a identidade de prostituta, como um "espartilho bem vermelho, bem puta, bem tudo", etc.). A negociação de tal identidade continua nas linhas 76, 77 e 78, nas quais Sandra pede a Daniela que a ensine um movimento corporal utilizado pelas travestis para exibir seus atributos físicos (colocando as mãos nos quadris, balançando os seios e mexendo lentamente a cabeça para jogar os cabelos de um lado para o outro). A referência a essa corporalidade nos mostra Sandra sublinhando o capital simbólico de Daniela nesse contexto e, dessa forma, empoderando sua posição de sujeito. A validação da identidade de Daniela como prostituta eficiente, que conhece as práticas simbólicas e corporais valiosas em seu território de prostituição, é enfatizada na linha 84, na qual Sandra menospreza sua própria capacidade para elaborar tal prática corporal ("se eu começá a balançá PLAFT cai tudo"), orientando-se desfavoravelmente a sua performance e deixando implícita, em comparação a Daniela, sua inabilidade para tal tarefa. A travesti, defrontada com a ineficiência da performance de Sandra, consolida sua superioridade de gênero indicando que Sandra "não pode balançar" (L. 85) o corpo do jeito que ela o faz. Essa negociação é interrompida no momento que um possível cliente passa de carro pelas interlocutoras. Daniela, sem titubear, o chama e, exibindo seu corpo, engajase no movimento que impossibilita Sandra de se construir, por meio de práticas corporais especificas, como uma eficiente profissional do sexo (processo interacional indicado pelas notas de campo que acompanham a transcrição).

Excerto 4

90 Daniela:

a loca!

91 Sandra:

ta meu amor.

92 Daniela:

93

ta meu amor. $(0,7)$ oi barbudinho vem cá amor/ ((chama um motorista de um carro e mostra seus seios, balançando o

94 Karla: $\quad$ vai!/ tchau beijo. 
No entanto, Sandra, em outra noite de intervenção, não se satisfez em somente pedir conselhos sobre como construir práticas corporais que a produzissem como profissional do sexo eficiente; ela as executa de fato, tentando imitar Michelly. Vejamos a seguir:

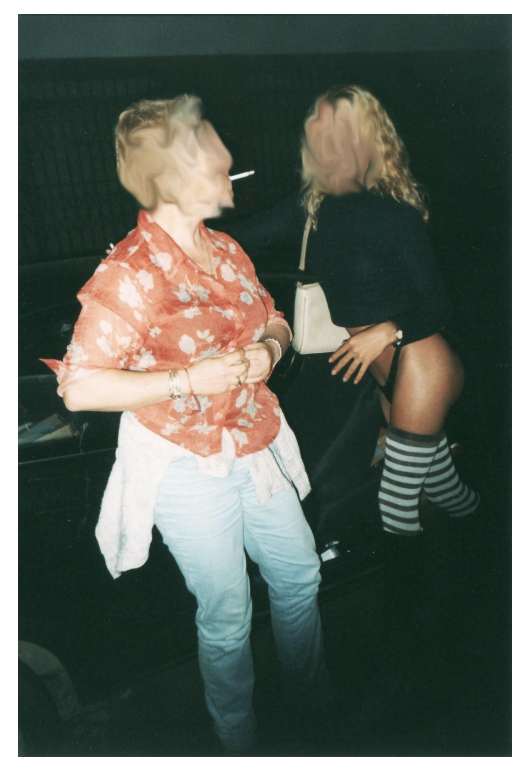

FIGURA 1 - Michelly ensinando Sandra a utilizar o corpo na batalha

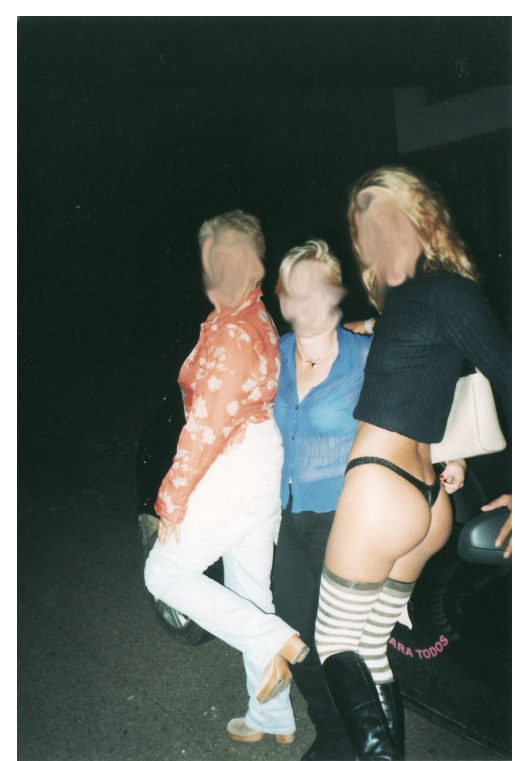

FIGURA 2 - Sandra tentado imitar Michelly exibindo suas formas corporais

Essas fotos foram tiradas pelo pesquisador em uma das raras vezes que as interventoras saíram do carro da ONG Liberdade durante o trabalho de campo. Infelizmente não pude gravar as falas que acompanham essas cenas, pois havia sido requisitado a manusear a máquina fotográfica. Porém, minhas notas de campo indicam que, antes de sair do carro, Sandra havia feito uso das ferramentas discursivas acima descritas para pedir a Michelly que a ensinasse a usar o corpo de forma que a interventora pudesse "fazer um aqüé" (i.e., fazer dinheiro) enquanto entregava preservativos naquela noite. Michelly prontamente convida Sandra a sair do carro e engaja-se em práticas que, segundo ela, atrairiam um bom número de clientes. Sandra tenta imitá-la (FIG.1), ameaça abrir a blusa para mostrar os seios e pega o cigarro das mãos da travesti. Na FIG. 2, posando para a máquina fotográfica, Michelly fica de costas e mostra a parte traseira de seu corpo, levantando uma de suas pernas. 
Sandra, sem titubear, tenta fazer a mesma pose afirmando que "meu edi não é como o dela" (i.e., minha bunda não é como a da Michelly).

As imagens acima são significativas, pois indicam que o processo de negociação das identidades das interventoras e das travestis pode extrapolar o nível linguístico e chegar ao nível das práticas corporais. O que me parece ser mais relevante aqui é que Sandra, segundo algumas informantes, é naturalmente mulher, dona da feminilidade que as travestis tanto ambicionam (posição contraditória, pois essencialista, vindo de indivíduos que transgridem suas limitaçôes biológicas na tentativa de construir-se em uma categoria social da qual não foram designadas ao nascer e que, assim, corporificam a possibilidade de uma mudança radical, disponível a qualquer um/a). Portanto, ao tentar imitar gestos e trejeitos típicos entre as travestis da Cidade do Sul, Sandra parece engendrar um processo de autenticação dessa identidade, indicando, pela sua tentativa de imitar Michelly, que sua feminilidade não é suficiente para que ela possa se tornar uma boa profissional do sexo. Aí vemos interpenetradas três das táticas de intersubjetividade descritas por Bucholtz e Hall (2003, 2004, 2005), a autenticação da performance de Michelly, a adequação à identidade travesti por meio da imitação de suas práticas corporais e a legitimação institucional de sua posição de sujeito. Tal legitimação é fruto da posição de Sandra na ONG Liberdade e na sociedade. A interventora, advogada da ONG, divorciada, mãe de três filhos, ao imitar Michelly, enfatiza o poder que a posição de sujeito da travesti tem no contexto onde estão inseridas e, assim, valida sua identidade e legitima institucionalmente a performance da feminilidade da travesti. Vê-se, portanto, que o corpo, como construção discursiva, tem papel fundamental na fabricação de identidades (SHILLING, 1997; MOITA LOPES, 2001; BORBA; OSTERMANN, 2007; 2008) e, no caso em tela, na consolidação de relações intersubjetivas entre as interventoras dos eventos de fala investigados.

Em outra noite de intervenção, Sandra e Márcia encontram as travestis Amanda e Lya. Sandra, ao ver Amanda, não dá as informações sobre as reuniōes que acontecem no dia seguinte e, orientando-se para as formas do corpo de Amanda, pede para que ela dê uma "viradinha" (L. 24) para exibi-lo.

\section{Excerto 5}

23 Amanda: =tudo bem?=

24 Sandra: $\quad=$ tudo bem. $>$ vira aqui. Vira $<$ ( $($ pede para Amanda

25

dar uma voltinha)) 


\begin{tabular}{|c|c|}
\hline 26 Amanda: & ((da uma voltinha para mostrar seu corpo)) \\
\hline 27 Sandra: & olha só::::::-olha só. \\
\hline 8 Márcia: & olha só:: \\
\hline 9 Sandra: & olha aqui. eu quero apresentá o Rô o nosso teacher \\
\hline 0 & de inglês. \\
\hline 1 Rod: & tudo bem?= \\
\hline Amanda: & $=$ oil tudo $[$ bem? \\
\hline Lya: & [prazer Lya. \\
\hline Márcia: & ((entrega os preservativos)) \\
\hline 5 Amanda: & brigada $=$ \\
\hline 6 Márcia: & e uma sacolinha pra vocês bota o lixo. \\
\hline Lya: & então ta. [Brigado. \\
\hline Márcia: & [ta::: não tenho certeza se tem gel amanhã \\
\hline andra: & alguma novidade $=$ \\
\hline Lya: & =não. tudo no mesmo. \\
\hline
\end{tabular}

Amanda tinha recentemente bombado, i.e., injetado silicone industrial (utilizado como lubrificante de máquinas) em seu corpo para arredondar mais suas formas, ${ }^{9}$ e Sandra, na tentativa de validar suas novas curvas, engaja-se em uma performance que nos remete à masculinidade hegemônica (MOITA LOPES, 2002), objetificando, condescendentemente, o corpo feminino da travesti e sua beleza. Nas linhas 27 e 28, Sandra e Márcia, enquanto Amanda faz um giro de 360 graus sobre o eixo de seu corpo, comentam sobre sua beleza, entoando "olha só" repetidamente. Esse processo de autenticação da performance corporal satisfatória (i.e., que se apropria de símbolos ideologicamente associados à feminilidade) de Amanda pode ter sido motivada por minha presença na interação. Logo após Amanda exibir seus atributos físicos, Sandra me apresenta como o "teacher de inglês" da Liberdade. ${ }^{10} \mathrm{~A}$ presença de um indivíduo com performance masculina durante essa interação pode ter sido a força motriz para que Sandra orientasse a interação à feminilidade de sua interlocutora. Tanto o pedido para que a travesti exibisse seu corpo para seus interlocutores quanto as interjeições de Sandra e Márcia com relação ao corpo de Amanda constituem orientações avaliativas (BUCHOLTZ; HALL, 2005) de sua performance de gênero feminino. Tal avaliação positiva, feita por duas

\footnotetext{
${ }_{9}$ Mais adiante faço uma breve descrição de tal prática.

${ }^{10}$ À época, eu estava envolvido em um projeto da Liberdade que consistia em ministrar aulas de língua inglesa para as travestis para prepará-las para um evento internacional que seria sediado na cidade e que traria muitos turistas (potenciais clientes das travestis).
} 
mulheres detentoras de capital de gênero (BENTO, 2006) nesse contexto, consolida a relação intersubjetiva de autenticação da identidade de Amanda que, como toda travesti, passa grande parte de sua vida tentando apropriar-se de formas corporais e simbólicas associadas às mulheres. Elogios tão enfáticos elaborados por mulheres (donas "naturais" da feminilidade que as travestis tanto almejam) servem como estratégias para enfatizar a produção satisfatória de uma performance de gênero que reproduz e reitera discursos da corporalidade feminina sobre um corpo biologicamente masculino.

No excerto que segue, Sandra, Márcia, Amanda e Lya engajam-se em uma relação intersubjetiva de autenticação do gênero de Amanda.

\section{Excerto 6}

64 Sandra:

65

e tu melhorô legal?

66 Amanda:

$(0,7)$

67 Sandra:

melhorei bastante=

68 Amanda:

$\mathrm{XX}$. tu nos deixo preocupada guria!

69 Sandra:

70

71

por quê?

72 Márcia:

porque:: apesar da gente assim não:: não convivê $(0,5)$

é uma preocupação.então uma guria BONITA- não modifica nada o que tu tem de bonito.

73 Lya:

74 Sandra:

75

76

77

78

79 Lya:

80 Márcia:

81 Sandra:

já tem muito.

játem demais [@@@@

[já já. olha por exemplo assim. eu vô te

dá um exemplo. a Fafá de Belém botô os peito no no seguro. eu acho que tu tem que botá o teu corpo porque tu não precisa mais- porque olha aqui ó tu da de dez a zero em muita bicha não [é verdade?

82 Lya:

$$
\text { [é verdade. [éél }
$$

[claro que dá.

então. e tu qué fazê o quê? botá mais o quê?

83 Sandra:

é:: não precisa

84 Márcia:

olha. eu acho que até a globeleza tu põe no chão.

85 Lya: @@@@@@@@@@.

86 Márcia:

@@@@@@.dezenove aninho né?

87 Sandra:

é::

88 Lya:

ai que saudade eu tenho da aurora da minha vida @@@@@

Como mencionado anteriormente, Amanda havia há pouco tempo se submetido a mais uma sessão para injetar silicone industrial em seu corpo. Porém, a injeção dessa substância não ocorreu como planejado: Amanda 
enfrentou alguns problemas de saúde após a sessão. As aplicações de silicone industrial não são realizadas por um/a profissional da saúde. Elas são feitas por outras travestis, chamadas de bombadeiras, que aumentam sua renda mensal prestando esse tipo de serviço. Durante uma sessão, a travesti a ser bombada fica deitada com meias de nylon amarradas na cintura e nas pernas, para evitar que o silicone escorra para lugares não desejados. O silicone é aplicado com agulhas de uso veterinário (mais grossas, o que permite que o silicone seja mais facilmente injetado). Após uma área ter sido bombada, coloca-se uma espécie de supercola ou esmalte de unha no furo feito pela agulha para evitar que o silicone saia do corpo. Tais aplicaçōes de silicone podem causar sérios problemas ao bem-estar e à saúde da travesti. Aconselha-se, como observado por Benedetti (2005), que a travesti recém-bombada tome algum tipo de antiinflamatório para evitar complicações causadas pela aplicação do silicone. Não são raros os casos de travestis cujo silicone se moveu no interior de seus corpos, causando deformações pela sua acumulação em lugares como os calcanhares e as pernas (KULICK, 1998).

Sandra, apesar de não conviver muito com Amanda (L. 69), soube dos problemas enfrentados por sua interlocutora. Preocupada, pergunta se ela havia se recuperado da infecção que a deixou alguns dias acamada. Amanda diz que está melhor. Nesse ponto da interação, a modificação do corpo da travesti (já arredondado e protuberante) torna-se o tópico sobre o qual o processo de validação da performance feminina de Amanda será reforçado. A interventora constrói uma relação intersubjetiva de autenticação do gênero de sua interlocutora através de duas ferramentas linguísticas. A primeira delas é o uso repetido de vocativos e adjetivos femininos (L. 69, 70, 74, 76, 77 e 79) que constituem índices que categorizam seus referentes como participantes de determinados grupos sociais (OCHS, 1992; BUCHOLTZ; HALL, 2004, 2005), as posicionando (DAVIES; HARRÉ, 1990) como participantes desses grupos. Com o uso frequente desses índices, Sandra enfatiza a performance de gênero feminino elaborada por Amanda.

Outra estratégia discursiva utilizada pelas funcionárias da Liberdade nesse processo local de validação é o ato de re-afirmar a beleza da travesti em contraste com outras travestis (L. 77, 78, 79 e 80) e com artistas brasileiras tidas como ícones de feminilidade (L. 75 e 83). A cantora Fafá de Belém, que "botou os peito no seguro" (L. 75 e 76), é utilizada como exemplo para enfatizar o belo corpo de Amanda que deveria, segundo Sandra, "botar o corpo" no seguro, pois, fica aí implícito, este é também um ícone de beleza e 
feminilidade. Sandra, então, afirma que sua interlocutora "dá de dez a zero em muita bicha aî" (L. 77 e 78), enfatizando que Amanda não precisa colocar mais silicone para ser feminina. Nesse ponto da interação, a interventora convida as outras participantes a validar as comparações que está fazendo (L.78, 79 e 80), perguntando se não é verdade o que diz. Lya e Márcia, em coro, concordam com a validação da feminilidade da travesti em questão (L. 79 e 80). Valendo-se do fato de Amanda poder ser considerada como mulata, Sandra, na linha 83, afirma que sua interlocutora tem um corpo mais bonito que o da Globeleza, símbolo da diversidade e da sensualidade do carnaval brasileiro ("até a Globeleza tu põe no chão"). Tal comparação parece ter como intuito a autenticação da feminilidade da travesti. Lya, companheira de Amanda na batalha, na linha 85 , dando continuidade ao processo de validação da beleza de sua parceira, enfatiza sua juventude ("dezenove aninho né") que, no universo trans (BENEDETTI, 2005), é muito valorizada, pois, nessa época, o corpo masculino é mais flexível e, assim, mais facilmente moldado com formas arredondas, associadas ao corpo feminino (KULICK, 1998; BENEDETTI, 2005).

\section{Distinção, desnaturalização e deslegitimação}

No corpus aqui analisado, processos que constroem relações intersubjetivas de distinção, desnaturalização e deslegitimação são virtualmente inexistentes. Nas interaçõos entre interventoras e travestis, há, como vimos, um grande envolvimento das interlocutoras em relações identitárias que sublinham a autenticidade e o capital simbólico que as performances identitárias das travestis têm nesse lócus sócio-cultural. Segundo Bucholtz e Hall (2004), as táticas de distinção, desnaturalização e deslegitimação envolvem "a ênfase dada a qualidades percebidas como distantes do eu e do outro" (BUCHOLTZ; HALL, 2004, p. 494). Parece-me que essas táticas não serviriam aos propósitos identitários localmente negociados entre interventoras e travestis. As intervenções parecem servir como palcos sobre os quais a travestilidade é produzida e consolidada, tanto por travestis quanto por interventoras. Ademais, um dos propósitos políticos da ONG Liberdade é o empoderamento das posiçōes de sujeito das travestis na Cidade do Sul. Propósito esse que é, discursivamente, levado às intervenções para educação de sexo seguro descritas acima, como as análises ilustram.

É, então, o empoderamento da travestilidade que parece impossibilitar o engajamento das interventoras em processos que desestabilizariam as 
performances identitárias de suas interlocutoras transgênero. No entanto, é interessante observar que, nos excertos 3 e 4 acima apresentados, a travesti Daniela produz uma relação intersubjetiva de distinção com relação à Sandra, desnaturalizando e deslegitimando a performance corporal de profissional do sexo que Sandra tentava engendrar. Talvez esse seja o único exemplo de processos pelos quais as identidades produzidas durante as intervenções são vetadas. Mas esse veto foi construído por uma travesti que, com base em sua performance corporal, chama a atenção para a incapacidade da interventora de construir-se como eficiente profissional do sexo. Assim, podemos inferir que o empoderamento da performance da travestilidade durante as intervençôes fornece possibilidades discursivas às travestis de construção de performances de gênero que as posicionam interacional e generificadamente superiores às funcionárias da ONG Liberdade. As alteridades das interventoras parecem servir de trampolim para que as identidades das travestis sejam empoderadas, validadas e intersubjetivamente consolidadas.

\section{Considerações Finais}

Comentando sobre o tema do trânsito, Fabrício (2006, p. 62) indica que "aprendemos na cultura a olhar com desconfiança para as misturas, os cruzamentos, as metamorfoses e a diversidade". No entanto, as interventoras da ONG Liberdade, por meio dos movimentos discursivos descritos, parecem direcionar esforços interacionais para a diminuição de suas diferenças sociais e identitárias em relação às travestis com quem trabalham. Tais movimentos indicam que as negociações de identidades, na prevenção de DST/AIDS, têm um papel crucial para que a tarefa institucional das interventoras possa ser executada. Mais significativamente, esses movimentos discursivos ilustram a importância da adaptação, do trânsito, da flutuação e das revisões identitárias (MOITA LOPES, 2006) em interações institucionais nas quais identidades díspares entram em contato. Os movimentos discursivo-identitários que emergem das intervençôes radicalizam a ideia de 'identidades multifacetadas' (MOITA LOPES, 2003; 2006; K. HALL, 2005; HALL, S., 2001; BORBA; OSTERMANN, 2007; 2008; BORBA, 2006; 2008a; 2008b), que é um dos postulados teóricos que moldam muitas das ciências sociais hoje em dia. $\mathrm{O}$ contato com identidades díspares, as (re)negociações identitárias, as flutuações e os trânsitos são parte constitutiva das interações e dos processos identitários em geral, processos que, na contemporaneidade, encontram-se exacerbados. 
Faz-se mister, então, trazer para o foco das pesquisas na Lingüística Aplicada e nas humanidades em geral, a pergunta: como lidamos, em nossas práticas discursivas diárias, com os deslocamentos de significados identitários antes entendidos como estáticos?

Os jogos de identidades (HALL, S., 2001) com os quais nos engajamos cotidianamente trazem à tona construçôes identitárias múltiplas e moventes. Essa maleabilidade identitária ilustra como as fronteiras entre as identidades são porosas, abertas para mudanças e transformações (locais e temporárias). Como vimos, o repertório de identidades das interventoras é afetado pelas travestis, e vice-versa. Em outras palavras, em nossas práticas discursivas, o eu e o outro se interpenetram, retro-alimentam-se e, dessa forma, produzem dinâmicas interacionais por meio das quais as fronteiras entre as identidades (de gênero, sexualidade, classe social, raça) podem ser ultrapassadas, sobrepostas, borradas ou até mesmo apagadas. Talvez a mensagem implícita das interações aqui analisadas seja a de "não resistir ao contato com o outro, não impor de antemão conceitos pré-estruturados [o que] não significa tornarse o outro, mas permitir ser atingido por ele" (DIAS, 2007, p. 89). As dinâmicas entre o eu e o outro indicam que não controlamos quem somos; o olhar do outro é crucial para que possamos nos movimentar em nossa vida social, o que engendra, como vimos, múltiplos e complexos processos de administração de diferenças (e semelhanças) entre interlocutores/as. Essa administração, no caso das intervenções, é marcada pelo trânsito por discursos de identidades, por ambiguidades, oscilações, pela mudança, pela adaptação, pelas mesclas de significados identitários múltiplos e, por vezes, contraditórios. Com a combinação de recursos discursivos, ao explorar possibilidades identitárias, interventoras e travestis fabricam múltiplas identidades, o que indica sua participação em universos linguísticos variados.

Ademais, o estudo sobre identidades em fricção pode nos fornecer subsídios para que entendamos os processos discursivos que produzem misturas e cruzamentos; entre-espaços que nos causam desconfiança e insegurança por trazer à baila significados identitários inauditos. Afinal, como essa proliferação de identidades do mundo contemporâneo afeta a construção cotidiana de nosso feixe identitário (MOITA LOPES, 2003)? Como indivíduos que se alocam em discursos de identidades considerados nãotradicionais negociam suas posições de sujeito em face das forças hegemônicas referentes a gênero, sexualidade, classe social, raça e profissão? E qual a consequência que esse espectro multifacetado de identidades ditas não- 
tradicionais traz para aqueles e aquelas que ainda se vêem atrelados a discursos de identidades normativos?

Possíveis respostas a essas perguntas são ilustradas neste trabalho. Embora tenha investigado somente um pequeno substrato dos amplos processos identitários contemporâneos, pode-se aqui vislumbrar possibilidades de construções identitárias múltiplas, motivadas, como se argumentou, pelas fricçôes entre as identidades das interventoras e das travestis. A análise das intervençôes da ONG Liberdade indica ainda que as interlocutoras orientamse a uma forma diferenciada de organização para a diferença. Vê-se que as fronteiras entre as performances habitualizadas das identidades tradicionais das interventoras e das posições de sujeito periféricas das travestis estão abertas para a interpenetração e para intercâmbios. Assim, os limites entre a igualdade e a diferença são tornados tênues, o que indica que a diferença pode ser uma fonte de engrandecimento de nossas experiências discursivo-identitárias. As práticas discursivas emergentes das intervençóes ilustram a possibilidade de contato positivo e enriquecedor com a diferença e, assim, indicam um porvir otimista para aqueles/as à margem de nossa sociedade. Oxalá esses processos de apagamento da diferença co-construídos por interventoras e travestis pudessem inspirar outros atores sociais a organizar suas práticas discursivas para a minimização da discriminação e do preconceito. Utopias à parte, devemos ter em perspectiva que as re-negociações das diferenças identitárias, as flutuações e os trânsitos são parte constitutiva das interações produzidas em contextos contemporâneos. Para entendê-los, faz-se, então, necessário lançar o foco das pesquisas sobre as dinâmicas que produzem tais deslocamentos e sobre seus efeitos na vida dos indivíduos que participam das práticas sociais que investigamos.

\section{Referências}

BAKHTIN, M. Estética da criação verbal.Trad. Paulo Bezerra. São Paulo: Martins Fontes, 1979/2003. 476p.

BAKHTIN, Mikhail. [1929]. Marxismo e filosofia da linguagem. Trad. Michel Lahud et alii. São Paulo: Hucitec, 1997. 203p.

BARRET, R. Markedness and style switching in performances by African American drag queens. In: MYERS-SCOTTON (Ed.). Codes and consequences: Choosing linguistics varieties. New York, Oxford University Press, 1998. p. 139-161. 
BARRETT, R. Indexing Polyphonous Identity in the Speech of African American Drag Queens. In: BUCHOLTZ, M; LIANG, A. C.; SUTTON, L. (Ed.). Rethinking Identities: The gendered self in discourse. New York: Oxford University Press, 1999. p. 313-331.

BAUMAN, Z. Identidade. Rio de Janeiro: Jorge Zahar Editor, 2005. 112p.

BENEDETTI, M. R. Toda Feita: o corpo e o gênero das travestis. Rio de Janeiro: Garamond, 2005. 144p.

BENTO, B. A reinvenção do corpo: sexualidade e gênero na experiência transexual. Rio de Janeiro: Garamond, 2006. 256p.

BESNIER, N. Sluts and Superwomen: The politics of gender liminality in urban Tonga. Ethos, v. 62, n. 1-2, p. 5-31, 1997.

BESNIER, N. Crossing Genders, Mixing Languages: the linguistic construction of transgenderism in Tonga. In: HOLMES, J.; MEYERHOFF, M. (Ed.). Handbook of Language and Gender. Oxford: Blackwell, 2003. p. 279-301.

BLOM, J.; GUMPERZ, J. O significado social na estrutura lingüística: Alternância de códigos na Noruega. 1972. In: RIBEIRO, B. T.; GARCEZ, P. M. (Org.). Sociolingüistica Interacional. 2. ed. São Paulo: Loyola, 2002. p. 45-84.

BOLIN, A. In search of Eve: Transsexuals' rites of pasage. South Hadley, MA: Bergin and Garvey, 1988. 193p.

BORBA, R. Lingüística Queer: Uma perspectiva pós-identitária para os estudos da linguagem. Entrelinhas, 2006. Disponível em: <www.entrelinhas.unisinos.br>. Acesso em: 7 jan. 2009.

BORBA, R. Alteridades em Fricção: discurso e identidades na prevenção de DST/ AIDS entre travestis. 2008. 170 f. Dissertação (Mestrado em Lingüística Aplicada - Interdisciplinar) - Faculdade de Letras, Universidade Federal do Rio de Janeiro, Rio de Janeiro, 2008a.

BORBA, R. Identidade e Intertextualidade: a construção discursiva do gênero e da sexualidade na prevenção de DST/AIDS entre travestis que se prostituem. Cadernos de Linguagem e Sociedade, Brasília, v. 9, n. 1, p. 72-97, 2008 b.

BORBA, R.; OSTERMANN, A. C. Do bodies matter? Travestis' embodiment of (trans)gender identity through the manipulation of the Brazilian Portuguese grammatical gender system. Gender and Language, v. 1, n. 1, p. 131-147, 2007. BORBA, R.; OSTERMANN, A. C. Gênero Ilimitado: a construção discursiva da identidade travesti através da manipulação do sistema de gênero gramatical. Revista de Estudos Feministas, Florianópolis, v. 16, n. 2, p. 409-432, 2008.

BORTONI-RICARDO, S. M. Problemas de comunicação interdialetal. Tempo Brasileiro, v. 78/79, p. 9-32, 1984. 
BUCHOLTZ, M. Why be normal? Language and identity practices in a community of nerd girls. Language in Society, v. 28, n. 2, p. 203-223, 1999.

BUCHOLTZ, M.; HALL, K. Language and Identity. In: DURANTI, A. (Ed.). A companion to Linguistic Anthropology. Oxford: Basil Blackwell, 2003. p. 268-294. BUCHOLTZ, M.; HALL, K. Theorizing Identity in Language and Sexuality Research. Language in Society, v. 33, n. 4, p. 449-515, 2004.

BUCHOLTZ, M.; HALL, K. Identity and Interaction: A sociocultural linguistic approach. Discourse Studies, v. 7, n. 4-5, p. 585-614, 2005.

CONNEL, R.; MESSERSCHIMIDT, J. Hegemonic Masculinity: rethinking the concept. Gender and Society, v. 19, n. 6, p. 829-859, 2005.

DAVIES, B.; HARRÉ, R. Positioning: The discursive production of selves. Journal for the Theory of Social Behaviour, v. 20, n. 1, p. 43-63, 1990.

DIAS, M. A pesquisa tem 'mironga': notas etnográficas sobre o fazer etnográfico. In: BONETTI, A.; FLEISCHER, S. (Org.). Entre saias justas e jogos de cintura. Florianópolis: Ed. Mulheres; Santa Cruz do Sul: EDUNISC, 2007. p. 73-92.

DU BOIS, J. W.; SCHUETZE-COBURN, S.; PAOLINO, D.; CUMMING, S. (Ed.). Discourse Transcription. Santa Barbara, CA: University of Santa Barbara Press, 1992.

EPPLE, C. Coming to terms with Navajo nadleehi: a critique of berdache, 'gay', 'alternative gender', and 'two spirit'. American Ethnologist, v. 25, n. 2, p. $267-$ 290, 1998.

FABRÍCIO, B. F. Lingüística Aplicada como espaço de "desaprendizagem": redescrições em curso. In: MOITA LOPES, L. P. (Org.). Por uma Lingüistica Aplicada INdisciplinar. São Paulo: Parábola Editorial, 2006. p. 45-65.

FABRÍCIO, B. F.; MOITA LOPES, L. P. Discursos e vertigens: identidades em xeque em narrativas contemporâneas. Veredas, v. 4, n. 2, p. 19-42, 2004.

FOUCAULT, M. O sujeito e o poder. In: DREYFUS, H; RABINOW, P. (Org.). Michel Foucault: uma trajetória filosófica para além do estruturalismo e da hermenêutica. Rio de Janeiro: Forense Universitária, 1995. p. 231-249.

GOFFMAN, E. Frame Analysis. New York: Harper \& Row, 1974. 600p.

GUMPERZ, J. J. Convençōes de contextualização. 1982. In: RIBEIRO, B. T.; GARCEZ, P. M. (Org.). Sociolingüistica Interacional. 2. ed. São Paulo: Loyola, 2002. p. 149-182.

HALL, K. "Unnatural” Gender in Hindi. In: HELLINGER, M.; BUSSMAN, H. (Org.). Gender across Languages: the linguistic representation of women and men. Amsterdam: John Benjamins, 2002. p. 133-162. 
HALL, K. Intertextual Sexuality: Parodies of class, identity, and desire in Liminal Delhi. Journal of Linguistic Anthropology, v. 15, n. 1, p. 125-144, 2005.

HALL, K.; O'DONOVAN, V. Shifting Gender Positions Among Hindi-speaking Hijras. In: BERGVALL, V; BING, J.; FREED, A. (Ed.). Rethinking Language and Gender Research: theory and practice. London: Longman, 1996. p. 228-266. HALL, S. A Identidade cultural na pós-modernidade. 5. ed. Rio de Janeiro: DP\&A, 2001. 102p.

KULICK, D. Travesti: sex, gender, and culture among Brazilian transgendered prostitutes. Chicago and London: University of Chicago Press, 1998. 269p.

KULICK, D. Transgender and Language: A review of literature and suggestions for the future. Journal of Lesbian and Gay Studies,v. 5, p. 601-622, 1999.

LINDSTROM, L. Context contests: Debatable truth statements on Tanna (Vanuatu). In: DURANTI, A.; GOODWIN, C. (Ed.). Rethinking Context: Language as an interactive phenomenon. Cambridge: Cambridge University Press, 1992. p. 101-124.

LIVIA, A. Disloyal to masculinity: linguistic gender and liminal identity in French. In: LIVIA, A.; HALL, K. (Ed.). Queerly Phrased: language, gender, and sexuality. New York: Oxford University Press, 1997. p. 349-368.

MOITA LOPES, L. P. Discurso, corpo e identidade: Masculinidade hegemônica como comunidade imaginada na escola. Gragoatá, Niterói, v. 11, p. 207-226, 2001. MOITA LOPES, L. P. Identidades fragmentadas. Campinas: Marcado de Letras, 2002. 232p.

MOITA LOPES, L. P. Discursos de Identidades. Campinas: Mercado de Letras, 2003. 272p.

MOITA LOPES, L. P. A construção do gênero e do letramento na escola: como um tipo de conhecimento gera o outro. Investigaçôes: Lingüística e Teoria Literária, Recife, v. 17, n. 2, p. 47-68, 2005.

MOITA LOPES, L. P. Lingüística Aplicada e a vida contemporânea: problematização dos construtos que têm orientado a pesquisa. In, MOITA LOPES, L. P. (Org.). Por uma Lingüistica Aplicada INdisciplinar, São Paulo: Parábola Editorial 2006. p.85-108. OCHS, E. Indexing Gender. In: DURANTI, A.; GOODWIN, C. (Ed.). Rethinking Context: Language as an interactive phenomenon. Cambridge: Cambridge University Press, 1992. p. 335-358.

PELÚCIO, L. Na noite nem todos os gatos são pardos: notas sobre a prostituição travesti. Cadernos Pagu, Campinas, v. 25, p. 217-248, 2005. 
PELÚCIO, L. No salto: trilhas e percalços de uma etnografia entre travestis que se prostituem. In: BONETTI, A.; FLEISCHER, S. (Org.). Entre saias justas e jogos de cintura. Florianópolis e Santa Cruz do Sul: Editora Mulheres e EDUNISC, 2007. p. 93-124.

PERES, W. S. Travestis: subjetividades em construção permanente. In: UZIEL, A. P.; RIOS, L. F.; PARKER, R. G. (Org.). Construções da Sexualidade: gênero, identidade e comportamento em tempos de Aids. Rio de Janeiro: Pallas, 2004. p. 115-128.

SARAMAGO, J. Todos os nomes. São Paulo: Companhia das Letras, 1997. 280p. SHILLING, C. The Body and Difference. In: WOODWARD, K. (Ed.). Identity and Difference. London: SAGE Publications, 1997. p. 63-107.

SILVA, H. R. S. Travesti: a invenção do feminino. Rio de Janeiro: Iser, 1993. 176p. SILVA, H. R. S. Certas Cariocas: Travestis e a vida de rua no Rio de Janeiro. Rio de Janeiro: Relume-Dumará, 1996. 120p.

SILVA, H. R. S.; FLORENTINO, C. A sociedade dos travestis: espelhos, papéis e interpretações. In: PARKER, R.; BARBOSA, R. M. (Org.). Sexualidades Brasileiras. Rio de Janeiro: Relume-Dumará, 1996. p. 105-118.

SILVERSTEIN, M. Language and the culture of gender: at the intersection of strutucre, usage and ideology. In: MERTZ, E.; PARMANTIER, R. J. (Ed.), Semiotic Mediation: Sociocultral and Psychologial Perspectives. Orlando: Academic Press, 1985. p. 219-259.

WIKAN, Unni. “The Omani xanith: A third gender role?" Man, v. 13, n. 3, p. 473-475, 1978.

Recebido em janeiro de 2009. Aprovado em fevereiro de 2009 


\section{ANEXO}

As convenções para as transcrições foram adaptadas de Du Bois, SchuetzeCoburn, Paolino \& Cumming (1992) e são as seguintes:

\begin{tabular}{|c|c|}
\hline MAIÚSCULAS & volume maior \\
\hline Negrito & parte da transcrição enfatizada para análise \\
\hline 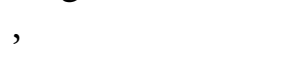 & entonação continuada \\
\hline & entonação decrescente \\
\hline ? & entonação crescente \\
\hline [ ] & sobreposição de fala \\
\hline - & palavra truncada \\
\hline - & enunciado truncado \\
\hline$=$ & fala colada \\
\hline$::::$ & som prolongado \\
\hline$>$ fala $<$ & fala mais rápida \\
\hline$<$ fala $>$ & fala mais lenta \\
\hline$(0.0)$ & tempo em segundos durante o qual não há fala \\
\hline$(())$ & informaçōes fáticas sobre a interação \\
\hline XXXX & $\begin{array}{l}\text { parte de fala inaudível; cada X representa mais ou menos } \\
\text { uma sílaba }\end{array}$ \\
\hline @@@ & risos \\
\hline * & entrega de preservativos \\
\hline
\end{tabular}

